\title{
Biochemical, Immunological and Toxicological Characteristics of the Crystal Proteins of Bacillus thuringiensis subsp. medellin
}

\author{
Sergio Orduz ${ }^{+}$, Thais Diaz, Nora Restrepo, Maria M Patiño, Martha C Tamayo
}

\author{
Unidad de Biotecnología y Control Biológico, Corporación para Investigaciones Biológicas, \\ Apartado Aéreo 7378, Medellin, Colombia
}

\begin{abstract}
Characterization of the insecticidal and hemolytic activity of solubilized crystal proteins of Bacillus thuringiensis (Bt) subsp. medellin (Btmed) was performed and compared to solubilized crystal proteins of isolates 1884 of $\mathrm{B}$. thuringiensis subsp. israelensis (Bti) and isolate PG-14 of $\mathrm{B}$. thuringiensis subsp. morrisoni (Btm). In general, at acid pH values solubilization of the $\mathrm{Bt}$ crystalline parasporal inclusions (CPI) was lower than at alkaline $\mathrm{pH}$. The larvicidal activity demonstrated by the CPI of Btmed indicated that optimal solubilization of CPI takes place at a $\mathrm{pH}$ value of 11.3, in Bti at $\mathrm{pH}$ values from 5.03 to 11.3 and in $\mathrm{Btm}$ at $\mathrm{pH}$ values from 9.05 to 11.3. Hemolytic activity against sheep red blood cells was mainly found following extraction at pH 11.3 in all Bt strains tested. Polyacrylamide gel electrophoresis under denaturing conditions revealed that optimal solubilization of the CPI in all $\mathrm{Bt}$ strains takes place at the alkaline $\mathrm{pH}$ values from 9.05 to 11.3. An enriched preparation of Btmed crystals was obtained, solubilized and crystal proteins were separated on a size exclusion column (Sephacryl S-200). Three main protein peaks were observed on the chromatogram. The first peak had two main proteins that migrate between 90 to $100 \mathrm{kDa}$. These proteins are apparently not common to other $\mathrm{Bt}$ strains isolated to date. The second and third peaks obtained from the size exclusion column yielded polypeptides of 68 and 28-30 kDa, respectively. Each peak independently, showed toxicity against 1st instar Culex quinquefasciatus larvae. Interestingly, combinations of the fractions corresponding to the 68 and 30 $k D a$ protein showed an increased toxicity. These results suggest that the $94 \mathrm{kDa}$ protein is an important component of the Btmed toxins with the highest potency to kill mosquito larvae. When crystal proteins of $\mathrm{Bti}$ were probed with antisera raised independently against the three main protein fractions of $\mathrm{Btmed}$, the only crystal protein that showed cross reaction was the $28 \mathrm{kDa}$ protein. These data suggest that Btmed could be an alternative bacterium for mosquito control programs in case mosquito larval resistance emerges to $\mathrm{Bti}$ toxic proteins.
\end{abstract}

Key words: Bacillus thuringiensis - crystal proteins - $\mathrm{pH}$-mediated solubilization - mosquito larval toxicity

Bacillus thuringiensis (Bt), an ubiquitous gram positive rod has been used in agriculture during the last 30 years to control insects. Since the discovery of the first mosquito active strain in 1977 by Goldberg and Margalit, it has been implemented worldwide in mosquito control programs. In recent years, an increased and extensive search for new strains of $B t$ have been performed in order to discover new or increased activities. Bt strains are toxic to either lepidopteran, dipteran, or coleopteran insects and some to nematodes (Höfte \& Whiteley 1989, Feitelson et al. 1992).

This bacterium produces crystalline parasporal inclusions (CPI) usually composed of one or several polypeptide subunits, which are toxic when

This research received financial support from Colciencias, the World Bank/WHO/TDR, and Corporación para Investigaciones Biológicas (CIB).

${ }^{+}$Corresponding author. Fax: 57-4-441.5514

Received 12 April 1995

Accepted 22 November 1995 ingested by susceptible insects. These CPI contain proteins that exhibit a variety of biological actions including cytolytic, hemolytic and entomocidal activities (Aronson et al. 1986, Höfte \& Whiteley 1989).

Numerous natural variations in the primary structure of the crystal proteins exist and are responsible for differences in susceptible host range of each toxin (Höfte \& Whiteley 1989). Many physicochemical properties of the crystal inclusions have been reviewed (Huber \& Lüthy 1981, Tyrrel et al. 1981, Pfannenstiel et al. 1986, Koller et al. 1992, Du et al. 1994) including the $\mathrm{pH}$ required for solubilization of the crystal, an important parameter, since it is an essential step for toxicity in susceptible insects. In this paper we describe the solubility, immunological, and toxicological properties of crystal proteins produced by $B$. thuringiensis subsp. medellin described by Orduz et al. $(1992,1994)$ and investigate the role of the individual proteins and their mixtures in toxicity to Culex quinquefasciatus larvae. 


\section{MATERIALS AND METHODS}

Bacillus thuringiensis strains and mosquitoes - Strains 1884 of Bt subsp. israelensis (Bti) and PG-14 of Bt subsp. morrisoni (Btm) were obtained from the Unite de Bacteries Entomopathogenes, Institut Pasteur, Paris. Strain 163-131 of Bt subsp. medellin (Btmed) was isolated from Colombia (Orduz et al. 1992). Bacteria were grown on LB agar plates (tryptone $10 \mathrm{~g}, \mathrm{NaCl} 10 \mathrm{~g}$, yeast extract $5 \mathrm{~g}$, agar $20 \mathrm{~g}$ per liter of distilled water), and incubated for $24 \mathrm{hr}$ at $30^{\circ} \mathrm{C}$. Tubes containing $5 \mathrm{ml}$ of liquid M-one medium (Proflo $1 \mathrm{~g}$, peptone $5 \mathrm{~g}$, glucose $3 \mathrm{~g}, \mathrm{~K}_{2} \mathrm{HPO}_{4} 6 \mathrm{~g}$, chloride salts $10 \mathrm{ml}$, containing $0.02 \mathrm{~g}$ of each one of the following $\mathrm{MgCl}_{2} \cdot 6 \mathrm{H}_{2} \mathrm{O}, \mathrm{MnCl}_{2} \cdot 4 \mathrm{H}_{2} \mathrm{O}, \mathrm{FeCl}_{3} \cdot 6 \mathrm{H}_{2} \mathrm{O}, \mathrm{ZnCl}_{2}$, and $\mathrm{CaCl}_{2} \cdot 2 \mathrm{H}_{2} \mathrm{O}$, phosphate buffer $200 \mathrm{ml}$, in 1 liter of distilled water and $\mathrm{pH}$ adjusted to 7.2) were inoculated and incubated for $8 \mathrm{hr}$ at $30^{\circ} \mathrm{C}$ and 200 $\mathrm{rpm}$. Bacterial cultures were transferred to $200 \mathrm{ml}$ of M-one, and incubated at $30^{\circ} \mathrm{C}, 250 \mathrm{rpm}$ in an environmental incubator shaker for two days. The final whole culture (FWC) was collected by centrifugation at $4^{\circ} \mathrm{C}, 9000 \mathrm{x} \mathrm{g}$ for $30 \mathrm{~min}$. The resulting pellet was treated for $30 \mathrm{~min}$ with $1 \mathrm{M} \mathrm{NaCl}$, washed twice in distilled water, resuspended in $1 /$ 20 of the original volume with distilled water and stored at $-20^{\circ} \mathrm{C}$ until needed. C. quinquefasciatus used in these experiments were field-collected in the vicinity of Medellin, and were maintained under laboratory conditions at $30 \pm 2^{\circ} \mathrm{C}$ under a $12: 12$ (light:dark) photoperiod.

pH-mediated solubilization of crystals - For solubilization assay, a universal buffer with constant ionic strength at several $\mathrm{pH}$ values was prepared as described by Koller et al. (1992). One hundred microliters of Btmed FWC was treated with $400 \mu$ of each one of the $\mathrm{pH}$ solutions of the buffer system, ranging from 2.55 to 11.22 , during $24 \mathrm{hr}, 30^{\circ} \mathrm{C}$ at $200 \mathrm{rpm}$. The solubilized proteins were dialyzed against phosphate buffer saline (PBS), (0.32 g NaH${ }_{2} \mathrm{PO}_{4}, 1.18 \mathrm{~g} \mathrm{Na}_{2} \mathrm{HPO}_{4}, 8.58 \mathrm{~g}$ $\mathrm{NaCl}$, per liter, $\mathrm{pH}$ 7.2). The solid material was collected by centrifugation, and its protein concentration was measured by Bradford's method (Bradford 1976). Aliquots of $400 \mu \mathrm{l}$ of the supernatant were acetone-precipitated, and proteins were separated on $10 \%$ sodium dodecyl sulfate polyacrilamide gel by electrophoresis (SDS-PAGE acrylamide-bis- $N-N$ ' acrylamide) (Laemli 1970).

Gel filtration - A sample of $12.5 \mathrm{mg}$ of the solubilized preparation of Btmed crystals purified by sucrose gradient centrifugation was loaded on a Sephacryl S-200 column (1 x 0.05 m.). Fraction elution was performed in a buffer system as described by Thiéry (1987), collected in $4 \mathrm{ml}$ samples and absorbance measured at $\mathrm{OD}_{280} \mathrm{~nm}$. Fractions from the Sephacryl column, were dialyzed against PBS pH 7.2. Samples of $400 \mu$ of the fractions were acetone-precipitated, and proteins separated on a $10 \%$ SDS-PAGE as described above.

Hemolytic activity assay - Sheep red blood cells were collected and washed three times in $0.85 \%$ saline solution (SS), and brought to a final concentration of $2.8 \%$ in SS. One hundred microliters aliquots of a fraction eluted from the Sephacryl column were mixed with an equal volume of a $2.8 \%$ suspension of sheep red blood cells in U-shaped bottom microtiter plates. Plates were incubated at $37^{\circ} \mathrm{C}$ with $5 \% \mathrm{CO}_{2}$ for $2 \mathrm{hr}$, then centrifuged at $500 \mathrm{x} \mathrm{g}$ for $10 \mathrm{~min}$ and absorbance of the supernatants was measured at $540 \mathrm{~nm}$ in a Multiskan MCC/ 340 ELISA reader.

Toxicity on mosquito larvae - Solubilized crystal proteins of Btmed separated in the Sephacryl column and the proteins extracted with the buffer system were tested for toxicity towards first instar C. quinquefasciatus larvae. Five, first instar $C$. quinquefasciatus larvae were placed in each one of a 24 well plate with $1 \mathrm{ml}$ of deionized water. Treatments were given to determine the $\mathrm{LC}_{50}$ of each one of the gel filtration fractions, and their mixtures. Each dose or $\mathrm{pH}$ extract was assayed twice, and experiments were conducted in four different days. Interactions between the different proteins of Btmed separated in the Sephacryl S-200 column were evaluated according to the formula described by Tabashnick (1992).

Preparation of antisera against Btmed crystal proteins and Western blot - Polyclonal antisera against individual Btmed crystal proteins were prepared in mice by weekly intraperitoneal injections of protein fractions separated in $10 \%$ PAGE-SDS. First injection was given in Freund's complete adjuvant, and other three injections in Freund's incomplet adjuvant. Crystal proteins of Btmed, and Bti were separated in a $10 \%$ SDS-PAGE and transferred to nitrocelulose paper. Western blot with antisera was performed by probing the membranes with antibodies raised against Btmed 94, 68, and $30 \mathrm{kDa}$ toxic proteins, diluted 1:500 and incubated at $4^{\circ} \mathrm{C}$ overnight. Other incubations were performed at room temperature in $\mathrm{TBS} \mathrm{pH} 7.4$, using $3 \%$ gelatin as blocking agent, and $0.05 \%$ Tween-20. For immunodetection, alkaline-phosphatase conjugated to Protein A was followed by a substrate/ color system composed of naphtol phosphate/Fast Red (Sigma Chemical Co.)

\section{RESULTS}

As a general trend, the alkaline treatment of CPI of all three $B t$ subspecies evaluated in this study, extracted higher amounts of proteins than acid treatment. The solubilized CPI of $B t$ subspe- 
cies evaluated in this study displayed hemolytic activity. The CPI of Bti, Btm and Btmed solubilized at $\mathrm{pH} 11.3$ produced $100 \%$ hemolysis in sheep red blood cell, while at the $\mathrm{pH}$ below this value, hemolysis was found between $0 \%$ and $30 \%$. Untreated FWC of Bti, Btm and Btmed caused 20\%, $15 \%$ and $10 \%$ hemolysis respectively (Table I).

On SDS-PAGE, CPI from FWC of Btmed showed polypeptides of 90-100 kDa, multiple bands at 80, 75, 67,65, 40, and 28-30 kDa (Fig. 2A, lane 2). CPI from FWC of Bti and Btm showed mainly protein bands of $144,135,125,67$, and 28 $\mathrm{kDa}$ when solubilized at $\mathrm{pH}$ values between 9.98 and 11.3 (Figs 2B, 2C, lane 2). The optimal solubilization of Btmed CPI takes place at pH 11.3 (Fig. 2A, lane 12), but crystal proteins could be observed also at $\mathrm{pH}$ values from 4.1 to 9,98 (Fig. 2A, lanes 5 to 11$)$. When tested on a bioassay challenging 1 st instar $C$. quinquefasciatus larvae, samples corresponding to lanes 6 to 11 (Fig. 2A), caused less than $62 \%$ mortality. Similarly to Btmed, crystals from $B t m$ show solubilized proteins at $\mathrm{pH}$ values between 4.1 and 11.3 (Fig. 2B, lanes 5 to 12); however, solubilized crystal proteins from Btm caused less than $50 \%$ mortality at $\mathrm{pH}$ values below 6.01 and more than $80 \%$ at $\mathrm{pH}$ values higher than 7.04 . Larval mortality was $100 \%$ only when crystals were solubilized at $\mathrm{pH}$ values from 9.05 to 11.3 (Fig. 1). In $B t i$, solubilized crystal proteins were observed mainly at $\mathrm{pH}$ values between 9.05 and 11.3 (Fig. $2 \mathrm{C}$, lanes 10 to 12 ), however more than $90 \%$ mortality of $C$. quinquefasciatus larvae was observed in $\mathrm{pH}$ values between 5.03 and 11.3 (Fig. 1). In Bti and $\mathrm{Btm}$, the $68 \mathrm{kDa}$ crystal protein was also observed when solubilization of the CPI took place at $\mathrm{pH}$ values of 5.03 and 6.01 respectively (Figs $2 \mathrm{~B}$ and $2 \mathrm{C}$, lanes 6 and 7, respectively).

Fractionation in Sephacryl S-200 of crystal proteins solubilized at alkaline $\mathrm{pH}$ showed three main peaks (Fig. 3A). Fraction 23 showed two protein bands when analyzed in SDS-PAGE (Fig. 3B, lane 3), which migrated between 90 to $100 \mathrm{kDa}$, with the most abundant protein component at approximately $94 \mathrm{kDa}$. For the larvicidal studies these fractions will be referred to as the $94 \mathrm{kDa}$ protein. The main polypeptide present in fractions 24 through 30 (lanes 4 to 10) migrated with a molecular weight

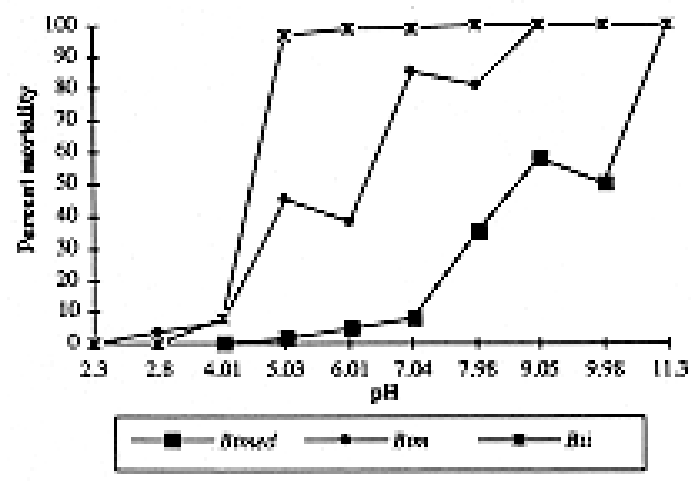

Fig. 1: mortality of first instar Culex quinquefasciatus larvae treated with the solubilized proteins at different $\mathrm{pH}$ values. Btmed: strain 163-131 of Bacillus thuringiensis subsp. medellin; Btm: strain PG-14 of Bt subsp. morrisoni; Bti: strain 1884 of $B t$ subsp. israelensis.

\section{TABLE I}

Protein concentration and hemolytic activity assay of Bacillus thuringiensis subsp. medellin, B. thuringiensis subsp. morrisoni and B. thuringiensis subsp. israelensis at different $\mathrm{pH}$ values

\begin{tabular}{|c|c|c|c|c|c|c|}
\hline \multicolumn{4}{|c|}{$\begin{array}{l}\text { Protein concentration } \\
\qquad(\mathrm{mg} / \mathrm{ml})\end{array}$} & \multicolumn{3}{|c|}{ Hemolytic activity $(\%)^{b}$} \\
\hline $\mathrm{pH}^{c}$ & Btmed & Btm & $B t i$ & Btmed & Btm & $B t i$ \\
\hline 2,3 & $<0,025$ & $<0,025$ & $<0,025$ & 0 & 5 & 5 \\
\hline 2,8 & $<0,025$ & $<0,025$ & $<0,025$ & 5 & 5 & 5 \\
\hline 4,01 & $<0,025$ & $<0,025$ & $<0,025$ & 5 & 5 & 5 \\
\hline 5,03 & $<0,025$ & $<0,025$ & $<0,025$ & 5 & 5 & 5 \\
\hline 6,01 & $<0,025$ & $<0,025$ & $0,06 \pm 0.02$ & 5 & 5 & 10 \\
\hline 7,04 & $<0,025$ & $0,06 \pm 0.02$ & $0,08 \pm 0.01$ & 5 & 5 & 15 \\
\hline 7,98 & $0,06 \pm 0.02$ & $0,05 \pm 0.02$ & $0,08 \pm 0.02$ & 5 & 10 & 10 \\
\hline 9,05 & $0,10 \pm 0.02$ & $0,05 \pm 0.02$ & $0,08 \pm 0.01$ & 5 & 10 & 10 \\
\hline 9,98 & $0,09 \pm 0.01$ & $0,08 \pm 0.04$ & $0,10 \pm 0.01$ & 10 & 30 & 10 \\
\hline 11,3 & $0,30 \pm 0.06$ & $0,29 \pm 0.10$ & $0,36 \pm 0.10$ & 100 & 100 & 100 \\
\hline FWC & $0,31 \pm 0.17$ & $0,24 \pm 0.08$ & $0,40 \pm 0.02$ & 10 & 15 & 20 \\
\hline
\end{tabular}

$a$ : protein concentration measured by Bradford's method; $b$ : solubilized proteins tested by duplicate and repeated in two different days; $c$ : $\mathrm{pH}$ at which the CPI were solubilized. $\mathrm{pH}$ was adjusted to 7.2 before hemolysis tests were set; Btmed: strain 163-131 of B. thuringiensis subsp. medellin, Btm: strain PG-14 of B. thuringiensis subsp. morrisoni, Bti: strain 1884 of $B$. thuringiensis subsp. israelensis; FWC: final whole culture. 


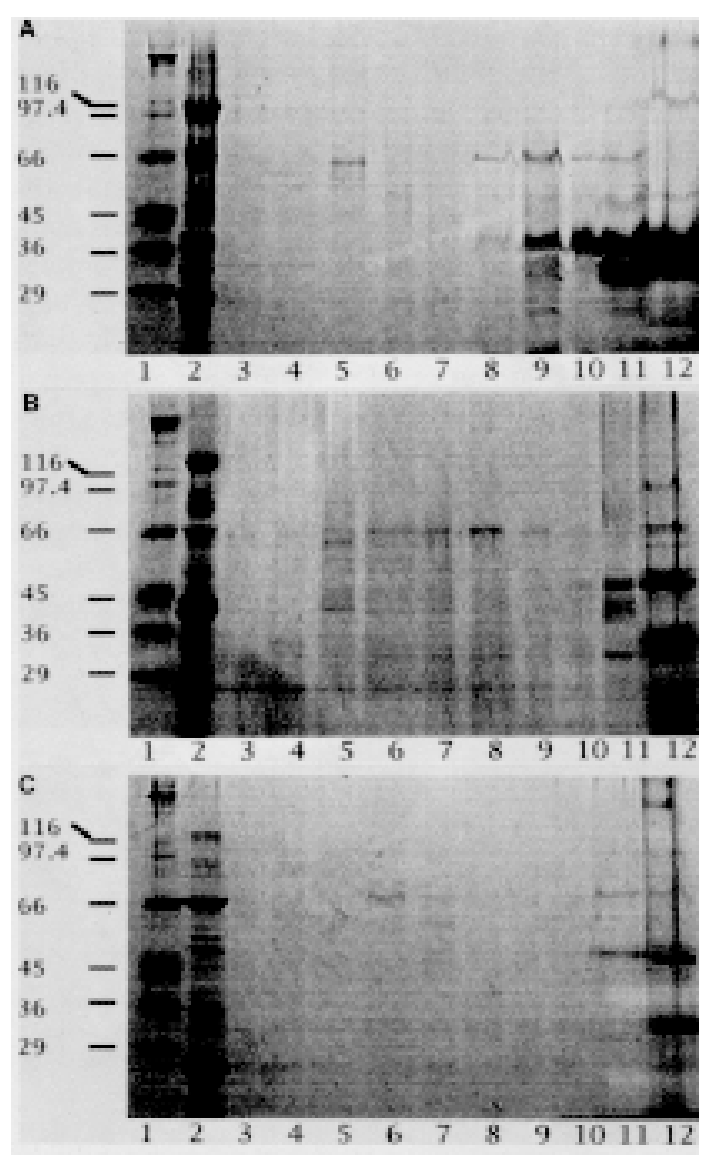

Fig. 2: SDS-10\% PAGE, Coomassie blue stained gels of (A) Bacillus thuringiensis subsp. medellin, (B) Bt subsp. morrisoni, (C) Bt subsp. israelensis final whole cultures treated at different $\mathrm{pH}$ values. Lanes 1 , molecular weight markers indicated in $\mathrm{kDa}$, lanes 2 crystal proteins from (A), B. thuringiensis subsp. medellin, (B), Bt subsp. morrisoni, and (C), Bt subsp.

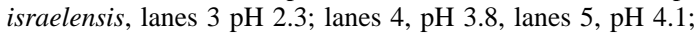
lanes 6, pH 5.03; lanes 7, pH 6.01; lanes 8, pH 7.04; lanes 9, pH 7.98; lanes 10, pH 9.05; lanes 11, pH 9.98; lanes 12, pH 11.3.

between 66 and $68 \mathrm{kDa}$. Fractions 32 and 33 (lanes 12 and 13) showed two main protein bands at approximately 28 and $30 \mathrm{kDa}$. Hemolytic activity was mainly found in fractions containing the $28-30 \mathrm{kDa}$ proteins (Table II).

The mosquito larvae mortality results obtained in the treatments with the fractions collected from the Sephacryl S-200 column indicate that the 94 $\mathrm{kDa}$ protein is perhaps the most important component of the Btmed toxins with an $\mathrm{LC}_{50}$ of $82.6 \mathrm{ng}$ of protein/ml (Table III). Proteins of 68 and $30 \mathrm{kDa}$ of Btmed have $\mathrm{LC}_{50}$ 's of 1256 and $1948.5 \mathrm{ng} / \mathrm{ml}$ respectively in $C$. quinquefasciatus first instar larvae. The effect of crystal protein mixtures of Btmed was also evaluated in bioassays with mosquito larvae, and results analyzed according to the formula described by Tabashnick (1992). Results indicate
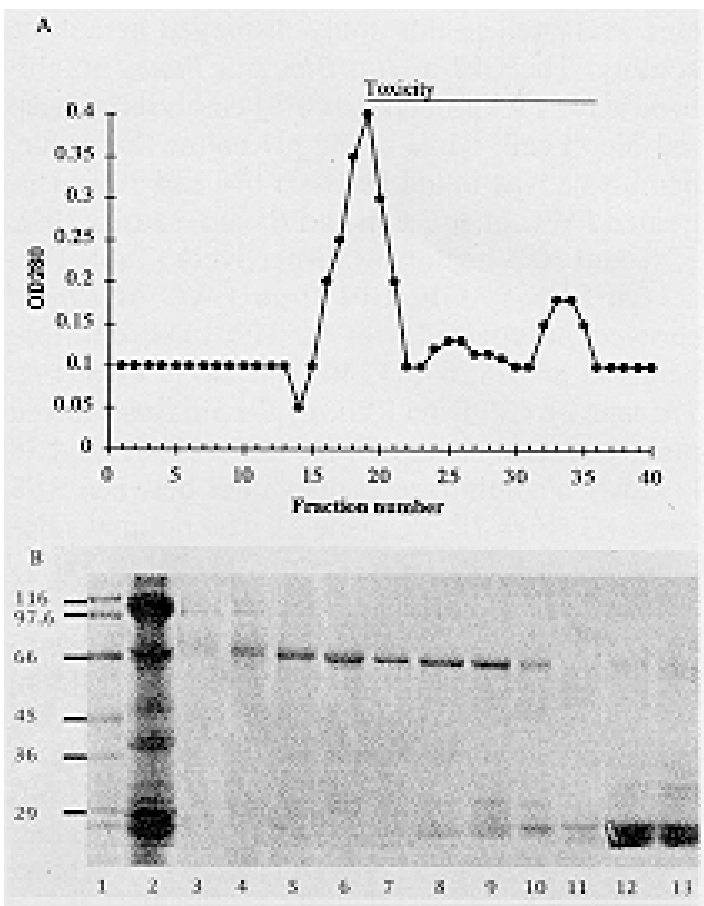

Fig. 3A: elution profile of the alkali solubilized Bacillus thuringiensis subsp. medellin crystal proteins from a Sephacryl S-200 column. Fig. 3B. SDS-10\% PAGE, stained with Coomasie Blue of fractions of Btmed crystal proteins eluted from a Sephacryl S-200. Lane 1, molecular weight markers indicated in $\mathrm{kDa}$; lane 2 final whole culture of Btmed lanes 3 through lane 12, fractions 23, 24, 25, 26, 27, 28, 29, 30, 31, 32 , and 33 respectively. Fractions causing mosquito larval mortality are indicated by a line.

\section{TABLE II}

Percent hemolysis of sheep red blood cells caused by different Bacillus thuringiensis subsp. medellin crystal proteins separated in a Sephacryl S-200 column

\begin{tabular}{lrc}
\hline $\begin{array}{l}\text { Fraction } \\
\text { number }\end{array}$ & $\begin{array}{c}\text { Size of protein } \\
\text { in kDa }\end{array}$ & \begin{tabular}{c} 
Percent hemolysis $^{a}$ \\
\hline 20
\end{tabular} $9^{2}$ \\
21 & 94 & 0 \\
22 & 94 & 0 \\
23 & 94 & 0 \\
24 & 94 & 0 \\
25 & 94 & 0 \\
26 & 68 & 0 \\
27 & 68 & 35 \\
28 & 68 & 35 \\
29 & 68 & 60 \\
30 & $28-30$ & 100 \\
31 & $28-30$ & 100 \\
32 & $28-30$ & 100 \\
33 & $28-30$ & 100 \\
34 & $28-30$ & 100 \\
35 & $28-30$ & 100 \\
\hline
\end{tabular}

$a$ : solubilized proteins tested by duplicate and repeated in two different days. 
that the mixture of the 94 and 68, and 94 and 30 $\mathrm{kDa}$ proteins did not interact synergistically; however the 68 and $30 \mathrm{kDa}$ proteins interact synergistically. The mixture of the fractions containing the 94, 68 and 28-30 $\mathrm{kDa}$ proteins produced a slight increase in toxicity compared to the expected, but this could not be considered a synergistic effect (Table III).

Crystal proteins of Btmed, and Bti were probed by Western blot with each one of the antisera raised in mice independently against the three main protein fraction of Btmed $(94,68$, and $30 \mathrm{kDa}$ proteins). The anti $94 \mathrm{kDa}$ and the anti $68 \mathrm{kDa}$ protein did not recognize any of the crystal proteins of Bti, while the anti $30 \mathrm{kDa}$ recognized the $28 \mathrm{kDa}$ protein of Bti (data not shown).

TABLE III

Observed and expected $24 \mathrm{hr}$ mortality of first instar Culex quinquefasciatus larvae treated with Bacillus thuringiensis subsp. medellin enriched fractions

\begin{tabular}{llc}
\hline $\begin{array}{l}\text { Toxin(s) } \\
\text { (proportions) }\end{array}$ & $\mathrm{LC}_{50} \mathrm{ng}$ of protein/ml (proportions) \\
\cline { 2 - 3 } observed & expected $^{a}$ \\
\hline 94 & 82.6 & \\
68 & 1256 & \\
30 & 1948.5 & 326.9 \\
$94+68(0.2: 0.8)$ & $430.4(86.1: 344.3)$ & 384.6 \\
$94+30(0.18: 0.82)$ & $373.8(67.3: 306.5)$ & 1582.1 \\
$68+30(0.42: 0.58)$ & $857.8(360.3: 497.5)$ & 358.2 \\
$94+68+30(0.1: 0.42: 0.48)$ & $351.8(35.3: 147.7: 168.8)$ & 358.2 \\
\hline
\end{tabular}

$a$ : calculated according to the formula described by Tabashnick (1992).

\section{DISCUSSION}

The $C$. quinquefasciatus larval mortality and sheep red blood cell hemolytic activity of the $B t$ CPI solubilized under different $\mathrm{pH}$ conditions correlates with the amount of protein extracted at each particular $\mathrm{pH}$ value. We also observed a constant tendency in which larvicidal and hemolytic activity of Bti crystal proteins were displayed at lower $\mathrm{pH}$ values than in Btm and Btmed.

The ability of the solubilized crystal proteins from Btmed to cause hemolysis suggests that most of the mosquitocidal strains of $B t$ identified to date contain cytolytic proteins (Thomas \& Ellar 1983, Gill et al. 1987). Furthermore, at least in Bti, Btm, and Btmed, this biological activity is caused by proteins of low molecular weight (20-30 kDa). In all the $B t$ subspecies that are active against mosquito at the $\mathrm{ng} / \mathrm{ml}$ level, there is an immunological cross reaction of the low molecular weight proteins. As in the case of Bti and Btm, it has been shown that the hemolytic proteins of Btmed are the low molecular weight components of the CPI. In particular, it has been shown that in Btmed, the 28$30 \mathrm{kDa}$ protein is responsible for the hemolytic activity, and that the various degrees of hemolysis caused by the $68 \mathrm{kDa}$ protein fractions could be due to contamination with small amounts of the 28-30 kDa protein during the gel filtration procedures. In the $\mathrm{pH}$ mediated solubilization experiments with all $B t$ strains tested, mortality and hemolytic activity increased with $\mathrm{pH}$ increase in the treatments. This indicate that most of the crystal proteins were solubilized at alkaline $\mathrm{pH}$ values.

Contrary to the data obtained by Koller et al. (1992) when working with CPI of Bt var san diego, we were unable to detect proteins in the acid extraction treatments under $\mathrm{pH}$ of 4.01 in any of the $B t$ strains tested. Gringorten et al. (1992) have demonstrated that solubilized CPI from $B t$ subsp. kurstaki required an alkaline environment in order to retain its full activity, however in our toxicity experiments, neutralization of the alkaline extraction treatments did not prevent expression of toxic activity as shown in Fig. 1.

The role of the four major polypeptides (CryIVA, CryIVB, CryIVD and CytA) of Bti in the mosquitocidal activity has been controversial (Wu \& Chang 1985, Ibarra \& Federici 1986, Pfannenstiel et al. 1986, Visser et al. 1986, Thiéry 1987). More recently, it has been demonstrated that the CytA protein is not essential for larvicidal activity on Culex and Aedes larvae (Delécluse et al. 1991) and that the CryIVA and CryIVB are responsible, for a major part of the toxicity to C. pipiens larvae in particular (Delécluse et al. 1991). Synergism between CryIVA and CryIVB has been shown by Angsuthanasombat et al. (1992), Delécluse et al. (1993). However, analysis of the data from Chilcott and Ellar (1988) evaluated by the method of Tabashnick (1992), demonstrated that the 27 $\mathrm{kDa}$ protein of $B t i$ interacts synergistically with the proteins of 68 and $130 \mathrm{kDa}$. The effect of crystal protein mixtures of Btmed was also evaluated in bioassays with mosquito larvae, and the results analyzed according to the formula described by Tabashnick (1992). It became clear that the only mixture that interact synergistically was that of 68 and $30 \mathrm{kDa}$ proteins (Table III). The mixture of the fractions containing the 94,68 and $28-30 \mathrm{kDa}$ proteins produced a slight increase in toxicity.

We have previously shown that differences in biological activity of Btmed, Btm, and Bti against C. quinquefasciatus, Anopheles albimanus, and Aedes aegypti, could be due to the absence of the $125-135 \mathrm{kDa}$ proteins in Btmed, the presence of the $94 \mathrm{kDa}$ protein in Btmed, the lack of immuno- 
logical similarity with the strains PG-14 of Btm and 1884 of $B t i$ or a combination of these factors (Orduz et al. 1992, 1994). The $94 \mathrm{kDa}$ protein is the most important component of the Btmed toxins with an $\mathrm{LC}_{50}$ of $82.6 \mathrm{ng}$ of protein $/ \mathrm{ml}$. This is in contrast to the observation made by Chilcott and Ellar (1988) who found that the most toxic component of the Bti crystal was the $68 \mathrm{kDa}$ protein with an $\mathrm{LC}_{50}$ of $4 \mathrm{ng} / \mathrm{ml}$.

The total immunological relationship of the crystal proteins of Bti and Btm has been demonstrated (Gill et al. 1987, Thiery 1987) and the 27 $\mathrm{kDa}$ crystal protein from these two subspecies differ only by one base and an amino acid change (Earp \& Ellar 1987, Galjart et al. 1987). In this study the main inmunological cross reaction was observed between the 28-30 kDa protein of Btmed and CytA of Bti, in agreement with the results of Orduz et al. (1994). In other mosquito-active strains immunological similarities between crystal proteins of Bti and crystal proteins of Bt subsp. fukuokaensis (Yu et al. 1987), and Bt subsp. darmstadiensis (Dobroniewski \& Ellar 1989) have not been observed. However, antibodies prepared against the 135 and $68 \mathrm{kDa}$ crystal proteins of $B t i$, recognized 70 and $26 \mathrm{kDa}$ crystal proteins from $B t$ subsp. kyushuensis (Held et al. 1990). In the opposite way, antibodies prepared against the crystal proteins of $B t$ subsp. kyushuensis recognizes crystal proteins of $B t$ subsp. israelensis, isolate PG-14 of Bt subsp. morrisoni, and Bt subsp. darmstadiensis (Ishii \& Ohba 1992). In the case reported by Held et al. (1990), monoclonal antibodies prepared against the crystal proteins of Bti showed no cross-reactivity. These data suggest that, in some way, the mosquitocidal strains of $B t$ share common epitopes, which could be suggestive of common structures.

The role of the $94 \mathrm{kDa}$ protein in the toxicity of the Btmed crystal which does not react with any of the three Bti antisera raised against CytA, CryIVD and CryIVA+B has been demonstrated. This study also provides pertinent information on the characteristics of the CPI of Btmed. The biological activity in this $B t$ subspecies is derived from proteins that are immunologically distinct from the previously known $B t$ mosquitocidal proteins. Furthermore, the hemolytic activity of the $28-30 \mathrm{kDa}$ protein of Btmed is in agreement with those of similar size and immunologically related toxins produced by Bti and Btm. Further studies with recombinant strains with Btmed and Bti genes will provide important information on the mode of action and relationship of these biologically important molecules, that could lead to implement Btmed or a recombinant bacterium with the Btmed toxin genes in mosquito control programs worldwide.

\section{REFERENCES}

Angsuthanasombat C, Crickmore N, Ellar DJ 1992. Comparison of Bacillus thuringiensis subsp. israelensis CryIVA and CryIVB cloned toxins reveals synergism in vivo. FEMS Microbiol Letters 94: 63-68.

Aronson AI, Beckman W, Dunn P 1986. Bacillus thuringiensis and related insect pathogens. Microbiol Rev 50: 1-24.

Bradford MM 1976. A rapid and sensitive method for quantification of microgram quantities of protein utilizing the principle of protein-dye binding. Analyt Biochem 72: 248-254.

Chilcott CN, Ellar DJ 1988. Comparative toxicity of Bacillus thuringiensis var. israelensis crystal proteins in vivo and in vitro. J Gen Microbiol 134: 25512558.

Delécluse A, Charles JF, Klier A, Rapoport G 1991. Deletion by in vivo recombination shows that the 28-kilodalton cytolytic polypeptide from Bacillus thuringiensis subsp. israelensis is not essential for mosquitocidal activity. J Bacteriol 173: 3374-3381.

Delécluse A, Poncet S, Klier A, Rapoport G 1993. Expression of cryIVA and cryIVB genes, independently or in combination, in a crystal-negative strain of Bacillus thuringiensis subsp. israelensis. Appl Environm Microbiol 59: 3922-3927.

Dobronieski FA, Ellar DJ 1989. Purification and properties of a 28-kilodalton hemolytic and mosquitocidal protein toxin of Bacillus thuringiensis subsp. darmstadiensis 73-E-10-2. J Bacteriol 171: 30603067.

Du C, Martin PAW, Nickerson KH 1994. Comparison of disulfide contents and solubility at alkaline $\mathrm{pH}$ of insecticidal and noninsecticidal Bacillus thuringiensis protein crystals. Appl Environm Microbiol 60: 3847-3853.

Earp DJ, Ellar DJ 1987. Bacillus thuringiensis var. morrisoni strain PG-14 nucleotide sequence of a gene encoding a $27 \mathrm{kDa}$ crystal protein. Nucleic Acids Res 15: 3619.

Feitelson JS, Payne J, Kim L 1992. Bacillus thuringiensis: Insects and beyond. Bio/Technology 10: 271-276.

Galjart NJ, Sivasubramaman N, Federici BA 1987. Plasmid location, cloning and sequence analysis of the gene encoding a 27.3 kilodalton cytolytic protein from Bacillus thuringiensis subsp. morrisoni (PG14). Curr Microbiol 16: 171-177.

Gill SS, Hornung JM, Ibarra JE, Singh GJP, Federici BA 1987. Cytolytic activity and immunological similarities of the Bacillus thuringiensis subsp. israelensis and Bacillus thuringiensis subsp. morrisoni isolate PG-14 toxins. Appl Environm Microbiol 53: 1251-1256.

Goldberg LJ, Margalit J 1977. A bacterial spore demonstrating rapid larvicidal activity against Anopheles sergentii, Uranotaenia unguiculata, Culex univitattus, Aedes aegyti and Culex pipiens. Mosq News 37: 355-358.

Gringorten JL, Milne RE, Fast PG, Soshi SS, van Frankenhuyzen K 1992. Suppression of Bacillus 
thuringiensis $\delta$-endotoxin activity by low alkaline pH. J Invertebr Pathol 60: 47-52.

Held GA, Kawanishi CY, Huang YS 1990. Characterization of the parasporal inclusion of Bacillus thuringiensis subsp. kyushuensis. J Bacteriol 172: 481-483.

Höfte H, Whiteley HR 1989. Insecticidal crystal proteins of Bacillus thuringiensis. Microbiol Rev 53: 242.

Huber HE, Lüthy P 1981. Bacillus thuringiensis deltaendotoxin: Composition and activation, p. 209-267. In EW Davidson Pathogenesis of invertebrate microbial diseases. Allenheld, Osmun, and Co., Totowa, N.J.

Ibarra JE, Federici BA 1986. Isolation of a relatively non toxic 65-kilodalton protein inclusion from parasporal body of Bacillus thuringiensis subsp. israelensis. J Bacteriol 165: 527-533.

Ishii T, Ohba M 1992. Immunological relationship between parasporal inclusions of Bacillus thuringiensis serovar kyushuensis and three other mosquito-specific Bacillus thuringiensis strains. J Gen Appl Microbiol 38: 385-389.

Koller CN, Bauer LS, Hollingworth RM 1992. Characterization of the $\mathrm{pH}$-mediated solubility of Bacillus thuringiensis var. san diego native delta endotoxin crystals. Biochem Biophys Res Comm 184: 692-699.

Laemmli UK 1970. Cleavage of structural proteins during the assembly of the head of bacteriophage T4. Nature 227: 680-685.

Orduz S, Diaz T, Thiéry I, Charles JF, Rojas W 1994. Crystal proteins from Bacillus thuringiensis serovar medellin. Appl Microbiol Biotechnol 40: 794-799.

Orduz S, Rojas W, Correa MM, Montoya AE, de Barjac H 1992. A new serotype of Bacillus thuringiensis from Colombia toxic to mosquito larvae. J Invertebr
Pathol 59: 99-103.

Pfannenstiel MA, Couche GA, Ross EJ, Nickerson KW 1986. Immunological relationships among proteins making up the Bacillus thuringiensis subsp. israelensis crystalline toxin. Appl Environm Microbiol 52: 644-649.

Tabashnick BE 1992. Evaluation of synergism among Bacillus thuringiensis toxins. Appl Environm Microbiol 58: 3343-3346.

Thiéry I 1987. Similarities between crystal protein subunits of Bacillus thuringiensis strain 1884 serotype H14 and strain PG-14 serotype H8a,8b, and their relationship with mosquitocidal activity. Ann Inst Pasteur/Microbiol 138: 457-470.

Thomas WE, Ellar DJ 1983. Bacillus thuringiensis var. israelensis crystal $\delta$-endotoxin: Effects on insect and mammalian cells in vitro and in vivo. J Cell Sci 60: 181.

Tyrell DJ, Bulla LA, Andrews RE, Kramer KJ, Davidson LI, Nordin P 1981. Comparative biochemistry of entomocidal parasporal crystals of selected Bacillus thuringiensis strains. J Bacteriol 145: 1052.

Visser B, van Wokum M, Dullemans A, Waalwijk C 1986. The mosquitocidal activity of Bacillus thuringiensis var. israelensis is associated with $\mathrm{Mr}$ 230000 and 130000 crystal proteins. FEMS Microbiol Lett 30: 211-214.

Wu D, Chang FN 1985. Synergism in mosquitocidal activity of 26 and $65 \mathrm{kDa}$ proteins from Bacillus thuringiensis subsp. israelensis crystal. FEBS Microbial Lett 190: 232-236.

Yu YM, Ohba M, Aizawa K 1987. Synergistic effects of the 65- and 25 kilodalton proteins of Bacillus thuringiensis strain PG-14 (serotype 8a:8b) in mosquito larvicidal activity. J Gen Appl Microbiol 33: 459-462. 
238 Characteristics of $B$. thuringiensis subsp. medellin crystals - Sergio Orduz et al. 